\title{
SCIENCE JOURNALISM FOR DEVELOPMENT IN THE GLOBAL SOUTH: A SYTEMATIC LITERATURE REVIEW OF ISSUES AND CHALLENGES
}

\author{
An Nguyen, Bournemouth University
}

Minh Tran, Bournemouth University \& Da Nang University of Science and Education

This is the accepted version of the above paper at Public Understanding of Science. There are substantial differences between this and the published version, which can be found at https://journals.sagepub.com/doi/abs/10.1177/0963662519875447? journalCode=pusa.

An Nguyen, PhD, is Associate Professor of Journalism at Bournemouth University, UK, and a former science editor from Vietnam. He has published, in the English language, three books and about 40 journal articles, book chapters and industry reports in several areas: digital journalism, news consumption, citizen journalism, science journalism, data journalism (including use/misuse of data and statistics in the media), and news and global development. His recent work includes News, Numbers and Public Opinion in a Data-Driven World (edited book, Bloomsbury, 2018), Developing News: Global Journalism and the Coverage of 'Third World' Development (coauthored, Routledge, 2017) and Data and Statistics in Journalism and Journalism Education, a special issue of Journalism (2016).

Minh Tran, MA (Cardiff), is Lecturer in Journalism Studies at Da Nang University of Science and Education, part of the University of Danang, Vietnam, and a PhD scholar at Bournemouth University, UK. Her main project examines news production and representation of global science controversies - such as AI, vaccination, GM food - in the Vietnamese media. She has published research in other areas such as gender issues in the news. 


\section{SCIENCE JOURNALISM FOR DEVELOPMENT IN THE GLOBAL SOUTH: A SYTEMATIC LITERATURE REVIEW OF ISSUES AND CHALLENGES}

\section{Introduction}

Science and technology (S\&T) has been a central part of international politics and policy since US President Harry Truman gave birth to the new post-war era of development, in which development replaced the colonial concept of civilisation as the dominant discourse for the West's influence on the rest of the world. As "the mission to develop the world" - namely to conquer poverty and solve the problems of underdevelopment - was fuelled by optimism about the exhaustible S\&T capacity of the developed world, "progress was accordingly expected to follow more or less automatically from the transfer of technology" (Naz 2006: 78). Today policy makers continue to see the globalisation of S\&T as a crucial means to alter human behaviours for the sake of economic prosperity, better living standards and personal freedom. Effective transfer of S\&T from developed countries, home to most scientific discoveries and technological inventions, to the less developed lies at the core of global policies and priorities, such as the UN's previous Millennium Development Goals and current Sustainable Development Goals.

In that context, the news media, as the most efficient of all available science channels (Nelkin 1995; Dutt and Garg 2000; Apiah et al. 2012), play a crucial role in preparing peoples and nations across the globe to exchange, choose and progress with the right S\&T ideas and approaches. Whether it is to provide information about scientific discoveries, to analyse science risks and benefits, or to lead society in science debates, journalism about science and technology (hereinafter called science journalism) is a vital force in raising global public awareness and action towards S\&T developments and related policies. While journalism alone cannot solve all science communication problems (it needs to work in tandem with direct, personalised communication modes to maximise its impact), few other channels would be able to match its still widespread reach and influence, at least at the level of gate-keeping, agenda-setting and awareness-raising. For the Global South - i.e. the grouping of so-called "developing countries" that are characterised 
by insufficient industrialisation and low Human Development Indices (low income, low life expectancy, and low educational attainment) ${ }^{1}$ - a strong base of professional science journalism would serve to moninor, inform and engage people with the continuous fast-pacing flow of S\&T, mainly from the developed North, into their daily socio-cultural, economic and political life. Such journalism is sorely needed in part because the above international development discourse can be problematic for the South for at least two key reasons:

First, it is based on a rather naïve belief in the North's sincerity and altruism in transferring S\&T to the rest of the world. In fact, as scholars (e.g. Escobar 1995, Lugo-Ocando and Nguyen 2017; Naz 2006; Obijiofor 2014) have demonstrated, this discourse was an outgrowth of the postcolonial Cold War geopolitics and its US-led development propaganda. Along numerous genuine efforts to bring modern $S \& T$ to South, there have also been ventures that are imbued with political and commercial interests of the governments and multinational/transnational corporations of powerful countries. Many places in the South, for example, have in the past become "dumping grounds" for the North's outdated technologies. If journalism could act as a critical observer and vigilant gatekeeper of science affairs and policies, it would be a key force to help the South avoid the risk of backward or unsustainable development.

Second, an excessive emphasis on S\&T as a panacea for all development issues, especially poverty eradication, can take place at the expense of other important things. As Lugo-Ocando and Nguyen (2017) argue, prioritisation of technological progress as a development pathway is not always desirable: it can potentially lead nowhere in terms of cultural coherence, social justice, happiness, health and wellbeing, and so on. This is especially crucial in the context that the South is more likely at the receiving than producing end of S\&T. Further, modern S\&T, while creating hopes for all sorts of human fears and longings, also poses potential threats to many established norms and values of life and humanity. Genetic modification, artificial intelligence, automation, stem cell research, nanotechnologies and the likes are transforming how we work, live and identify ourselves in unprecedented directions that even citizens and policy-makers of advanced, scientifically savvy societies, let alone those of the less advanced, find it hard to grasp, monitor

\footnotetext{
${ }^{1}$ For quick references, we used the list of developing countries defined in the IMF's World Economic Outlook 2017 as a guide to include or exclude a country in our analysis. These countries are located across Asia, sub-Saharan Africa, Middle-East, Eastern Europe and Latin America.
} 
and control. An informed and critical science journalism would assist the South's progress and growth in that respect.

Thus, the professional practice of science journalism in the Global South is of significant importance to the course of national, regional and global development. Yet our understanding of such practice - particularly its strengths and weaknesses, opportunities and challenges and its potential impacts on public understanding of and engagement with S\&T and related policies - is rather thin and disparate. Research shows that, although the past few decades have seen a steady increase in scholars' interest in science journalism, as a professional practice and as news content, this increase is primarily found in Western contexts, with non-Western data and perspectives remaining rather scarce (Schafer 2010). When we conducted an exhaustive three-stage search of the relevant academic literature for this work, we found a total of only 157 outputs from dozens of top English-language media journals and books over an 18-year period (see Box 1). Take Public Understanding of Science, for example. Our manual search of its archive between 2000 and 2017 resulted in only 24 papers that have science journalism in developing countries as the major subject or focus. This is out of a total of 1003 articles published by this premier journal during this period, representing a miniscule proportion of $0.02 \%$. Such imbalances in research, as Schafer (2010) points out, are in direct conflict with the notion and nature of science as a global system. In 2013, the Journal of Science Communication published an editorial calling for more scholarly attention to voices and perspectives from the less known developing parts of the world (Massarani 2013).

This paper is an initial attempt to address this gap. Based primarily on a thematic analysis of the above academic research sample (see Box 1), we present a general snapshot of the current state of science journalism in the South as it is portrayed in the academic literature. In particular, we recapitulate and reflect on observations by scholars about how science journalism is practised in developing countries, how it might influence public engagement with science, how it interacts with other stakeholders in science communication, what issues and challenges it faces, and what can be done to tackle them.

We should caution from the outset that, in subsuming a wide range of countries under the generic labels of "developing world" and "Global South", our account carries an unavoidable risk of over-generalisation. There is no "one size fits all" approach: it is simply impossible for a single 
paper to capture, within a short space, numerous peculiar issues in such vast, scattered swathes of lands, regions, nations and cultures. Also, given the rather "thin" and geographically uneven body of existing research into science journalism in the South, what we present below might suffer from some unknown inherent biases caused by inadequate knowledge. Apparently, as our analysis is based solely on the English-language scholarly literature, it is likely to have missed many relevant issues that are more thoroughly discussed in non-English languages of developing nations. With that in mind, however, we did detect some characteristics, issues and challenges that science journalism across developing countries share. These include (a) heavy dependence on foreign sources, especially the news media of the Global North; (b) low status of domestic science news in newsrooms; (c) uncritical science reporting that can easily lend itself to influences of vested non-science interests; (d) tight grips of politics on science journalism; and (e) ineffective relationships between science and journalism.

\section{Heavy reliance on foreign sources}

One of the most noticeable themes in our sample of research articles is that science news in developing countries is heavily driven by international sources, especially the news media in developed countries. The majority of science content in African media is translated from European or North American media outlets (Shanahan 2006), with little or no localised context (Tagbo 2010) and rare comments from domestic scientists (Joubert 2007). Likewise, developing parts of Asia have been found to source most of their science news output from stories originally published in the Western media. For example, half of the identifiable sources in Indian newspapers are from outside the national border, mainly uncritically duplicated from Reuters, AP, the New York Times and AFP newswire (Dutt and Garg 2012). The repackaging of science news from Western wire services is especially common in topics related to global science controversies as local journalists face more challenges in finding and eliciting local experts' views on those issues (Joubert 2007). In China, Tolan (2007) reports that $90 \%$ of online news stories on climate change are "recycled" from Western media or science institutions' reports without any local comments and regional linkages. A more recent assessment (Han and Lu 2017) shows that foreign officials are still the most frequently sourced in Chinese newspaper framing of climate change. In Latin America, 
Mercado (2012) observes from Argentina that newspaper coverage of topical scientific issues such as climate change is mainly found in foreign/international affairs rather than environment or science sections. Massarani et al. (2005) and Massarani and Buys (2007), studying newspapers in nine Latin American countries, find that they, while providing some considerable space for local and regional science events and issues, still pay far more attention to the so-called "First World" topics. In many cases, science news is "republished without enough concern in adequating to local reality" (Massarani et al. 2005, p. 5).

One key reason for such reliance on foreign sources, as Joubert (2007) emphasised, is that big science achievements are rarely originated from local laboratories or universities within their countries. When such rare cases happen, they are often published in international scientific journals in the first instance. As Cameroon journalist Buma Gana admits, African "scientists are unknown at home" (as quoted in Shanahan 2006, p. 392) since good African academic research is normally published in the West rather than within their countries of origin (Shanahan 2006; Joubert 2007). Some changes, however, have been noted, at least in the emerging economies. In China, which has seen a phenomenal growth in $\mathrm{R} \& \mathrm{D}$, there has been an increasing favour of domestic over international sources in science news reporting (Soete 2016). In India, which has seen many great achievements in domestic science (UNESCO 2010), longitudinal studies of English-language dailies' science and technology coverage by Dutt and Garg $(2000,2012)$ show that indigenous sources are gaining increasingly equal and, in some cases, even more prominent, profile than foreign sources. Similarly, Brazilian print and television news has seen increasing references to new science and technology developments at local institutions (Massarani and Buys 2007; Ramalho et al. 2012). This is possibly in part because Brazilian science - which enjoys a substantial investment rate per GDP that is relatively equal to that of Canada and the UK - has reached a mature and advanced stage where it has much to offer the local media (UNESCO 2010; Soete 2016). In fact, Brazil is the world's $13^{\text {th }}$ largest producer of science papers on Thomson Reuters Science Citation Index during 2011-2016 and 15 ${ }^{\text {th }}$ highest publisher on Scimago's journal and country rankings for the period between 1996 and 2017.

The heavy reliance on foreign sources troubles many observers for many reasons. Without an adequate understanding of basic science processes and some background knowledge about the science subject in original sources, translators are often poorly positioned to fully understand 
and/or critically assess foreign research reports and science news stories, let alone to crosscheck or transfer science facts and messages effectively into the local context (UNESCO 2007; Plessis 2008). Added to that is the high risk of information being mistranslated, miscommunicated and/or distorted due to vocabulary incompatibility or lapses in the use of science terminologies and language (Patairiya 2014; Massarani 2014). The Internet opens journalistic translators in the lowincome countries to many scientific resources that could help improve their ability to diversify and, to some extent, verify their foreign science news output substantially (Gray et al. 2012). At the same time, however, inadequate science knowledge, coupled with increasingly intense time pressures and scarce resources, means that they - and their local publics - are vulnerable to the increasing prevalence of unchecked, unsubstantiated science information, rumours and fake news on digital media. Sometimes, the consequence can be severe and fast. For example, in 2007, stories about a new US study, which finds a link between grapefruits and breast cancer among pregnant women was mistranslated from The Daily Mail and BBC News Online sites in several Vietnamese newspapers, causing an immediate collapse of the local grapefruit market (Nguyen 2014).

Researchers, therefore, have called for journalists in the South to focus more on researching local stories, linking local events to global knowledge, and humanizing their storylines (Mazzonetto 2005; Olet and Othieno 2015). That, however, remains wishful, as science journalism in the developing world still has a long way to professionalism, due to a range of socio-political and professional impediments that we examine in the next sections.

\section{Science journalism in the "back seat"}

Apart from the easy option of translating science stories from the international media, our collected material clearly shows that domestic science developments in the Global South rarely receive an adequate and proper attention by editors and news executives (Mwale 2006; Le and Navarro 2011; Lublinski et al. 2014). Despite the critical importance of science in development processes and the typical nation-building "development journalism" ideals of the South, science journalism enjoys rather low status and, for the most part, takes a back seat in daily newsroom operations because editors do not often perceive it as "selling". Research in Asia and Africa has 
found over the years that science-related topics are allocated comparatively little space and often used as space/time fillers, rarely as leading news items, and occasionally left out to give the space for last-minute paid advertisements (Dutt and Garg 2012; Ekanem 2003; Michael and Binta 2013; Schanne and Spurk 2009). In that climate, not surprisingly, dedicated science teams and sections are a "luxury" in newsrooms. In Pakistan, Bangladesh, Nepal and Central America, the media see regular ups and downs, with continuous launches and closures, of science sections and shows due to the lack of a professional will and/or financial support (Ahmed 2005; Patairiya 2007; Massarani 2014). Even in emerging economies such as China, India and Brazil, where the close link between science and development is more recognised and where there is a relatively advanced and fastgrowing S\&T sector, science journalism is not yet a fully recognised concept and still faces an uphill battle to establish its legitimacy as just another news beat (Dickon 2012; Navarro et al. 2010, Ramalho et al. 2012; Zhao et al. 2014; Massarani 2015).

Given that general of interest and investment, convincing editors to do a story has been cited as the most formidable daily challenge to science journalists in the South, in addition to poor working conditions, such as low pay and excessive work pressures (UNESCO 2007). To win editors' favour, science reporters often have to focus heavily on "newsworthy" topics or "selling" aspects of events or issues - those that either involve a high level of novelty, drama and controversy or are at heart of daily concerns, such as health and environment issues (Appiah et al. 2012; Appiah et al. 2015; Bauer et al. 2013; Massarani and Buys 2007; UNESCO 2007; UNESCO 2011; Majumda and Saikia 2011; Dutt and Garg 2012). In Nepal and Pakistan, for instance, reporters tend to devote time and energy to debatable nuclear power issues as these are more palatable to local publics and can thus contribute to audience revenues (Patairiya 2007; Navarro et al. 2011). In most countries, according to UNESCO (2011), health/medical topics receive the most attention, often followed by environment issues. In Brazil, health accounts for approximately half of the headlines in science newscasts on television (Ramalho et al. 2012). In India, the dominance of medical/health was so overwhelming that Dutt and Garg (2010), in a study of S\&T coverage in Indian dailies, decided to exclude them from their sample to avoid biases.

Focusing efforts on selling stories to editors means sacrificing or ignoring many topics that are critical to development in the Global South. For example, although developing countries are among the most vulnerable to climate change's long-term impacts, such as sea-level rise, flooding, 
drought, forest fires and biodiversity loss, climate change news in many Southern countries is not as prevalent as it should be, in part because of the abstract, distant and process-based nature of these issues (Raj and Sreekumar 2011; Wahyuni 2017). When climate change is the subject of the news, its essence is not always the focal point. Peruvian newspapers, for example, tend to prefer game-type to issue-type schema in reporting climate policy, i.e. they concentrate on the political and rhetorical skills of politicians, rather than the nature of the climate issues and approaches at stake (Takahashi 2011). Even in the "hot" areas of health, however, many important issues still do not always occupy a position that they deserve. For instance, although HIV/AIDS, which is classified among the most severe direct heath threats to people in the South (Lancet 2016), enjoys a more prevalent position than most other science topics, overall media attention to it is still deemed to be insufficient in many countries, including Uganda (Linda 2000), Nambia (Mchombu 2000; Chanda et al. 2008), Zambia (Kasoma 2000), China (Gao et al. 2013) and Tanzania (Kothari 2015).

\section{The scarcity of critical science reporting}

Alongside the low editorial commitment to science topics comes another prevalent issue: the lack of comprehensive, critical science news reporting in the Global South. This is reflected in several key aspects. First, there is the dominance of straight news in science coverage. When science events and issues appear in the media, they are predominantly covered as straight news. In Africa, UNESCO (2011) found that $85 \%$ of science media content takes the form of short, straight news stories. In the Philippines, these account for more than eight in ten science stories (Navarro et al. 2011; Evans 2015). This overwhelming proportion of straight news suggests an overall preference for episodic, event-based science news over thematic, issue-based coverage. Zhang et al.'s (2015) content analysis shows, for example, that Chinese print coverage of health issues has seen a gradual rise in episodic framing over the year. The lack of issue-oriented news reporting is especially common in countries of lower income, where news of long-term science-related issues peaks during special events (e.g. climate summits, World AIDS Awareness Day) or during short periods of intense debates, but does not last long enough to sustain public interest (Prat et al. 2002; 
Shanahan 2009; Boykoff 2010; Panopio and Navarro 2011; UNESCO 2011; Kakonge 2012; Das 2012; Kuppuswamy and Maheswari 2014).

Second, a dominance of straight news means that there is a lack of analytical coverage through in-depth journalistic forms as features, commentaries and the like. The body of scholarly research in our sample clearly shows that the media in developing countries often fail to present $\mathrm{S} \& \mathrm{~T}$ events and issues with an adequate evaluation of the scientific rigour behind them - such as methodological strengths/weaknesses, weight of evidence, scientific consensus, ethical conduct, and so on (e.g. Castelfranchi et al. 2014; DeRosier et al. 2015; Du and Rachul 2012; Jurberg et al. 2009; Lü 2009; Midttun et al. 2015; Navarro et al. 2011; Ogbogu et al. 2013; Panopio and Navarro 2011, Masood 2005; Ramalho et al. 2012). Shanahan's (2009) review of climate coverage in 12 countries, for example, finds that, except for India, such coverage rarely employs scientific facts to support or substantiate stories, or to analyse causes and effects. One oft-mentioned symptom of the lack of an analytical dimension in science news reporting is the media's tendency to either excessively celebrate the benefits or exaggerate the risks of new science discoveries or emerging technologies. Reis (2008), comparing how Brazilian and American newspapers frame stem-cell controversies, found that the former tend to be overexcited, focusing far too much on its medical advancements with celebratory language such as "dramatic", "revolutionary", or "promising" while ignoring the fact there is no sufficient evidence for their effectiveness.

Third, to further complicate the picture, there seems to be little effort to improve the quality of science journalism in the South. About a quarter of our sampled journal articles point to the lack of specialist training as one of the most formidable obstacles. As it stands, general reporters are all too often assigned to cover topics such as medicine, climate change, nuclear power, biotechnology, nanotechnology and so on (Shanahan 2009; Kankoge 2011; Aram 2011; Bauer et al. 2013; Appiah et al. 2015). Lacking essential science knowledge and specialist reporting skills, such generalists are unable to critically understand, monitor and engage lay publics with new science developments and their implications. Instead of the active pursuit and rigorous examination of science sources, for instance, they often conceptualise and develop stories on the basis of available research reports, press releases or PR events (Massarani 2014). 
This becomes even more problematic in the context that various forces other than science are increasingly at work to exercise excessive influence on science news in many countries. As journalists in the South are unable to evaluate science, they too often hold a loose grip on vestedinterest groups from political, corporate, religious and civil-society camps, which can sometimes lead scientific consensus to easily lose ground to non-scientific forces (Mercado 2012). Ogbogu et al. (2013) reveal that Chinese newspaper coverage of controversial and unproven stem-cell therapies is overly supportive with stories that underestimate risks, amplify benefits and treatment effectiveness. This overexcitement, according to the authors, is due in part to the influence of the resourceful stem-cell industry's efforts to shape public perception of China as a dream destination for stem-cell treatment provision. As genuine scientific substance is not sufficiently provided, lay publics find it hard to grasp the underlining scientific uncertainties around the positives and negatives of these therapies to make the right decision for their health and wellbeing. Similarly, in the area of GM food, while countries such as Kenya, Brazil and India see an overwhelmingly proGM news coverage, others - such as Zambia, Thailand and, to some extent, China - have witnessed the opposite, for reasons that have less to do with scientific evidence and more to do with mere beliefs and irrational fears, many of which are projected in the journalist's mindset by anti-GM interest groups (DeRosier et al. 2015; Masood 2005; Mwale 2006; Yang et al 2014).

For instance, in China - where many believe that GM is an American technology aiming to reduce its productivity and prevent it from becoming a global power (Lynas 2017) - Yang et al. (2014) find that GM news stories tend to abandon scientific stances in favour of an ethical position that allows the construction of anti-GM frames, often with the aid of anti-GM sources such as food safety activists and NGOs. In 2002, as a long-lasting South African famine pushed one third of its population into starvation, the Zambian government quite astonishingly rejected aid from the UN World Food Programme for the reason that the food aid took the form of US-farmed GM maize, to which Zambian media had been opposed in an uncritical and overtly biased but fierce manner, (Masood 2005; Mumba 2007). As Zambian publics were not equipped enough to engage in the debate and were not given opportunities to hear voices from opposite sides, they were easily manipulated by the risk-focused media reporting and deliberation of GM maize. Such coverage amplified the fear of giant US biotech companies being behind the food aid, thus creating immense pressures on the Zambian government to reject it. In fact, a blanket ban on GM soon followed this 
event - again, on the unfounded fears over its impacts on human health trigged by the media with the aid of environmental and other anti-GM interest groups - and was not lifted until early 2019.

\section{Political grips on science reporting}

A distinctive factor that stands out as a primary reason for the dearth of critical science journalism in developing countries is the political grip on science journalism across countries. This is reflected clearly in the dominance of political sources in science news output. Midttun et al. (2015) found from an analysis on climate change news in China that politicians and public officials accounted for $65 \%$ of sources in 2008 and $76 \%$ in 2010. In the Philippines, Navarro et al (2011) found that government accounts for $37 \%$ of sources in print coverage of agricultural biotechnology during 2000-2009, outweighing any other stakeholder, including civil society (22\%), international groups (16\%), universities and R\&D institutions (14\%), and private industry companies (11\%). Another study of GM coverage about GMOs during 1999-2010 in six major newspapers from six

Southeast Asian countries (Cambodia, Indonesia, Malaysia, the Philippines, Thailand and Vietnam) found that politicians and government officials were the most frequent source, being used in $59 \%$ of all stories and that the intensity of political sources increases on par with the level of press freedom of a country (Asoro 2012).

State control methods take various forms, depending on the political system of a particular nation. In heavily authoritarian systems (such as China and Vietnam), the state would not hesitate to use overt control, including legalised restrictions, over science news output. This includes tactics to implicitly or explicitly restrain science reporting to certain topics and issues and to ensure that political sources (government agencies and policy-makers) control science discourse and debate in the news. State actors in such countries often make deliberate attempts to restrict scientists from independent involvement in public debates, for fears that scientists might emphasise issues and arguments that are not in line with or even against their science and science-related policy (Jia and Liu 2014). In Vietnam, for example, scientists, as employees of state organisations, are required to seek persmission from their institution's heads before talking to the media (Nguyen 2014). Although these rules are not always observed, such control leads scientists to maintain a high level 
of self-censorship, with many tending to avoid participating in mediated science debates for fears of being politically manipulated (Zhang 2015).

In more democratic systems, political intervention is often through the control of access to science information. In India, the world's biggest democracy, most R\&D activities are under the control of the government, posing a huge challenge for journalists who want to investigate what is happening behind the wall of research institutions (Patairiya 2014). Also, as science journalists in many (if not most) developing countries work in the public sector, they are unlikely to critically question or investigate the state's national R\&D policies and initiatives. Often, that would mean over-reliance on press releases and research reports from state-controlled institutions. In addition, as government agencies attempt to restrict public access to state-funded research publications, journalists find it hard to report certain science topics in less descriptive and more analytical manners. Without in-depth advice by independent experts, pro-government voices dominate the news, giving the state an easy ride on what kind of S\&T a country should and could adopt or avoid for its own development priorities.

\section{The uneasy relationship between journalism and science}

Politics aside, there is an epistemological clash between scientists and journalists. We have seen from Northern contexts that the science-journalism relationship is traditionally an uneasy, sometimes acrimonious one, although this tension has attenuated somewhat in recent times (Nelkin 1995; Peters 2013). In the South, one might reasonably expect that more fundamental development issues would demand or necessitate the need for a much closer collaboration between science and journalism. This, however, does not seem to be the case.

From their camp, journalists lament insufficient support and cooperation from the science community and find it hard to keep in touch with local science institutions to follow, monitor and report on new science developments (Appiah et al. 2012; Bauer et al. 2013). Meanwhile, scientists do not regard communication as an important part of their professional duty (Zhao et al. 2014; Ndlovu et al. 2016), seeing the job of bringing science to the mass as that of the media. The few who are conscious of public communication as a scientist's social responsibility often have heavy 
workloads and/or lack knowledge and skills to work effectively with journalists and audiences (Ndlovu et al. 2016). When they do get involved, another set of issues arise. Scientists often place themselves in a superior position to journalists. For example, scientists often criticise journalists for conscious or subconscious misrepresentation of their work, lamenting about being misquoted, trivialised and the like (Olet and Ethieno 2015). Added to that is the wariness that news of their research is not always as positive as they expect (Joubert 2007; Michael and Binta 2013). In some places, such as Nigeria, scientists distrust the media also because the latter treat them like mere advertisers and demand them to pay for the publication of science stories (Ekanem 2003).

Many studies in our sample demonstrate that the uneasy, untrusting and sometimes hostile relationship between newsrooms and science institutions results from different perceptions of their roles in the communication process (e.g. Zhao et al. 2014; Jia and Liu 2014; Zhang 2015; Ndlovu et al. 2016). One common practice by scientists, for example, is to insist on reading pre-published copies and assume their right to make change to anything that they do not like in stories, which is hard for journalists to accept by their professional standards (Joubert 2007). Also, the two sides differ deeply in their approaches to science framing and representation. While journalists strive to make science easy to understand and appealing to lay audiences by focusing on research findings and their practical meanings, scientists prioritise scientific accuracy, which often demands detailed explanations of scientific processes and their limitations. Further, as journalists avoid the use of single sources and viewpoints in order to observe their professional norms of balance, fairness and impartiality, scientists criticise them for generating unnecessary controversies over many science issues. As both sides attempt to control what information to deliver and how to deliver it, without acknowledging and conceding to the other's ways of working, conflicts constantly occur.

The ineffective cooperation between science and journalism represents a critical challenge to public engagement with S\&T in developing countries, especially in the area of global science controversies. In such stories, journalists in the South have limited access to international science sources beyond those being appearing in the media of the North (UNESCO 2007; Bauer et al. 2013). Even with easy access to a huge amount of data and information in the digital environment, they still face other obstacles, such as language difficulties and lack of general science knowledge, that inhibit them from grasping new science developments and/or filtering the good from the bad (Nguyen 2014). Without sufficient collaboration from science institutions, the media are left alone 
to analyse and make imported S\&T accessible, relevant and meaningful to local publics (Joubert 2007). One reason for many international science news stories with a potentially direct impact on the daily operation in developing countries are translated from foreign media with little localisation is that it is too difficult for their reporters to locate and access relevant local scientists for ideas.

\section{Concluding notes}

This work, as cautioned at the outset, is not without potential flaws, especially in relation to the unknown bias and the risk of over-generalisation inherent in the rather thin body of available English-language literature about science journalism in the Global South. However, as the first systematic review of relevant research in this area, this paper offers some important perspectives and insights that can serve as reference points for future examinations of issues around the South's science journalism and its impacts on national and global developmental causes and processes.

First, this review further affirms the immense need for an informed, critical and vigilant professional science journalism in the South. Earlier, we identified the vital role of such journalism in gatekeeping and engaging developing populations with the fast-pacing global flow of S\&T. If done well, it would be instrumental for the South to make better S\&T decisions for development causes and to avoid the potential trap of undesirable, unsustainable techno-deterministic progress and growth. Our review further suggests that this function is not only vital but almost exclusive to the media of the South, because other key stakeholders in science communication - such as the science establishment, the civil society and the political elite - are unlikely to provide alternative avenues for meaningful science information and engagement. As discussed, scientists and science institutions do not have a strong flavour, incentive or expertise for public outreach and engagement initiatives. Meanwhile, the political elite of the South tend to see science and development policymaking as a domain of their own rather than one within the public sphere. And, under authoritarian rules typical of the developing world, non-governmental organisations and civil-society groups do not exist in strong forms and shapes to independently promote science and health issues. As a combined result of all these, in addition to other factors such as high economic costs, people in developing countries do not have much access to informal science communication platforms that 
are taken for granted in advanced societies - such as science museums, science cafes, exhibitions, festivals of learning, and so on. Thus, as soon as they are out of formal education systems (which are themselves often slow in keeping up with the pace of science), the only real channel for them to keep themselves informed of and engaged with S\&T and its related issues is the news media.

Second, it is reasonable to conclude that despite the central role of S\&T in development, journalism of the developing world has not done a good job in bringing science to the fore of that process. This is due to both internal problems of the news industry (such as editors' low regard for and half-hearted commitment to science news, the lack of specialist training for science journalists) and external forces (e.g. commercial and political interests, the reluctance of scientists and their institutions). That is not to say that science journalism has not contributed to the development of the Global South. If we accept the above argument that science journalism has an exclusive role in informing and engaging laypeople with science in the South, then we have to recognise that any substantial improvement in public understanding of science - and there has been certainly a lot of that over the past decades - is thanks at least in a substantial part to the efforts of the media.

Neither is it to say that the above problems are unique to developing countries: science journalism in advanced societies are not completely immunised from many of them, especially the lack of investment in science news, poor relationships between science and journalism, the reliance on press releases and so on. However, we should note two things:

One, the consequences of science journalism's problems can be more exacerbated in the South, where they work often in tandem with many other peculiar challenges. In other words, the same professional flaw of science journalism can have far worse direct consequences on the South than the North. The "medialisation" of science news, for example, is nothing unfamiliar to the North (Bauer 1998; Wormer 2014), but it probably exists at a dearer price to the South, because it would leave out many S\&T topics that are instrumental to development causes, such as poverty reduction, social justice and so on. In the absence of alternative science communication platforms, for example, the media's negligence of the potential risks and benefits of emerging technologies e.g. GM food, nanotechnology and artificial intelligence - can weaken the ability of the South, as adopters of technologies, in dealing with them in the long run. The ultimate consequence is that developing countries lags even further in already uneven globalisation processes. 
Two, the generally lower level of media literacy and the less democratic nature of their socio-political enviroment mean that the South have fewer civil and institutional mechanisms that exist to bring journalism's professional issues to the public's consciousness and conscience as well as to help its practitioners to tackle them. For science journalism, that translates into not only the "unfortunate pleasure" of facing few external pressures to reform but also the existence of less support for reform intiatives. Philanthropic funders for science journalism that are not uncommon in the North (e.g. Knight Foundation, Wellcome Trust), for instance, are rare in the South. In many places, capacity building for the media has been done mainly at the support of international public or private donors, who themselves are not always free to support what they wish to support.

That said, however, this research suggests that journalism about science in the South could reform itself to eliminate some of the unhelpful impacts that it has made on the social and economic wellbeing of developing societies. Although some of the perennial constraints, such as government control, lie in macro socio-political structures and are not easy to eliminate in any short term, others - such as the excessive reliance on foreign sources, the lack of critical science reporting (especially in relation to science risks and benefits), or the ineffective working partnership with local scientists and science-related organisations - are within the capacities of the media to change. Since 2006, the World Federation of Science Journalists, through its peer-to-peer mentoring projects in Africa, the Middle East, Latin America and Southeast Asia, has instigated some positive changes (Nguyen 2014; Gervais, Lubinski \& Marc-Fleury 2012), but limited funding means that their impacts cannot be brought to the next stages. Nevertheless, these programmes have created for each participating country/region a core group of aspiring, relatively well-trained reporters who could act as its science journalism pioneers. Many of these have since established their professional networks or associations at home, and although their impacts remain limited, they are the first essential steps for science journalism in the South in its long journey to professionalism. For these networks to materialise their potential, however, they need much more coordinated, holistic support from news industries, funders, the science establishment, governments, NGOs and the public. 


\section{Acknowledgements}

An early version of this paper was presented as a Top-Five Paper in Global Communication for Social Change at the $69^{\text {th }}$ Conference of the ICA. The criticisms and suggestions of the three PUS reviewers have since helped to considerably improve the manuscript. 


\section{Box 1: Sampling and analytical procedures for this systematic review}

In order to be as exhaustive as possible, this systematic review employs a three-phase search strategy to retrieve peer-reviewed English-language articles about science journalism in developing countries (see Figure 1). In the first phase, we used a series of Boolean key strings to search the ESBCOhost platform for relevant research about science, environment and health journalism in developing countries. ESBCOhost was used for two reasons. Firstly, it is a vast "one-stop shop" of articles from 27 international research databases, with 3000 e-journals and 170.000 e-books. Secondly, each ESBCOhost search result is presented clearly with a title and an abstract, helping researchers to effectively and efficiently screen the synopsis of the work at stake. After exclusion of all invalid and duplicated results, we obtained 73 eligible articles.

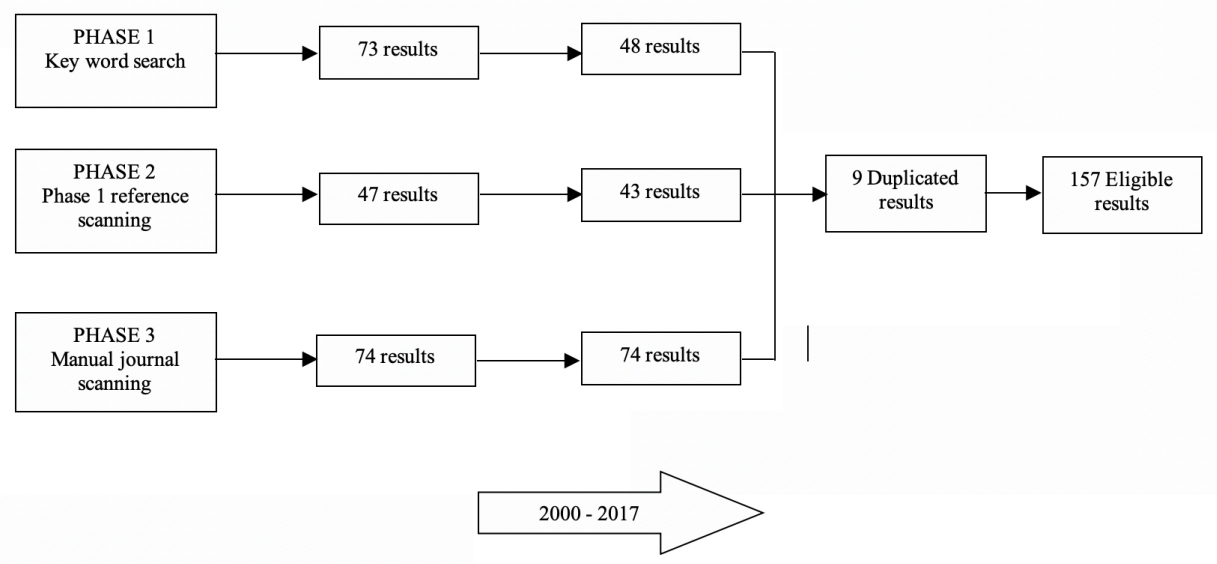

Figure 1: Three-phase sample collection

In the second phase, we searched through the references of the above 73 articles for other relevant research (snowball sampling). Those articles whose titles and abstracts include news and journalism about science, health and environment issues in the developing world, were chosen for examination. 47 results were found from this phase, making a total of 120 studies from the first two phases. However, many of these date from decades ago, making them rather irrelevant for a systematic review of contemporary science journalism in developing countries. Therefore, we decided to eliminate a total of 21 studies published before 2000 , resulting in a 
sample of only 91 publications between 2000 and 2017. This time frame allows us to gain insights into the status of science journalism of the $21^{\text {st }}$ century in the Global South.

In the third phase, as an attempt to avoid false negatives in keyword search terms and to supplement the ESBCOhost search, we manually collected relevant studies from ten highranking journals that are likely to include research about science in the news. By scanning all titles and abstracts from these journals between 2000 and 2017, we obtained 74 studies on science journalism in developing countries. 61 of these came from the three journals specialised in science communication: 24 from Public Understanding of Science, 20 from Science Communication and 17 from Journal of Science Communication. The rest was distributed among Journalism: Theory, Practice \& Criticism (five), Journalism Studies (two), Journalism \& Mass Communication Quarterly (two), Journal of Communication (two), Journalism Practice (one), and Communication Research (one). European Journal of Communication had no relevant study to be included in the sample.

After a further exclusion, we arrived at a total of 157 peer-reviewed publications between 2000 and 2017. The vast majority of these (139) are journal articles, with the rest including three book chapters, nine research reports by NGOs, and seven outputs in other formats (e.g. theses, features and commentaries in peer-reviewed journals with journalistic flavour, such as Nature). The thematic analysis was based on this sample, with the occasional aid of supplementary material collected from a Google search of the open web.

As for analytical procedures, the corpus was analysed for two dimensions: (a) the current state of English-language research into science journalism in the Global South; and (b) the issues and challenges to such journalism that this body of research observes. For practical reasons, we have excluded the characteristics of the research corpus - such as geographical scopes, research subjects and focuses, research designs, specific methods and so on (see Nguyen and Tran 2019) - to focus this paper on issues and challenges. For this part, our review was initially informed by the first author's insights from his role as a monitor and assessor of SjCOOP Asia, a training project of the World Federation of Science Journalists in Southeast Asia during 2012-2014 (Nguyen 2014). This experience suggested us to focus on three broad areas as a general guide for our detailed thematic analysis. First, we explored the characteristics of science news content 
that are often observed in the corpus at stake. Second, we examined research into science journalism in the context of newsroom cultures and processes in order identify its key internal challenges. Finally, we turned attention to science journalism's relationships with key stakeholders in science communication - such as the science establishment, policy-makers, the public and the civil society - to examine external obstacles that emerged as important from the research corpus. [Initially, we did search for professional facilitators rather than just challenges or obstacles but decided to drop them as the vast majority of the sampled papers do not offer enough materials/evidence for such positive factors.]

Using that guide, we started with an open coding process, manually extracting relevant textual segments (passages, phrases and words) for each sampled paper. After continuous rounds of filtering and refinement, we came up with a list of nearly 50 different codes - each representing a specific content trait (e.g. dominance of straight news, naïve assumptions, sensationalism, superficiality, dominance of non-science sources), an internal challenge (e.g. editors' indifference, poor pay, heavy workload) or an external obstacle (e.g. state control of science research, scientists' hostility). The initial codes, especially those that could fall under different labels, were examined and re-examined through a constant comparison process to minimise overlapping and to form sub-themes (each sub-theme is a group of small codes that indicate or reflect the same underlining phenomenon). For example, the initial codes of "editors' indifference to science topics" and "editors" non-science background" were later organised under a sub-theme called "editors' low interest in science journalism". This sub-theme was then combined with several others (e.g. heavy workloads) to form one of the five primary themes of this paper (science journalism in the back seat). The five umbrella themes were constructed to bear close relationships with and/or implications for the development issues discussed in the introduction. It should be noted that while some sub-themes were organised on the basis of high frequencies of appearance in the corpus (see Nguyen and Tran 2019 for concrete data about the most frequent sub-themes), less prevalent ones were also constructed either because of their importance for their "mother" theme, or because they can complement others towards a mother theme, or because they can serve as connecting points between and amongst sub-themes and themes. To add depth to the data, we also looked for specific cases and examples and used some of them to illustrate themes, sub-themes and codes throughout this paper. 


\section{References}

Ahmed, A., 2005. Barriers to science journalism in Pakistan [online]. Available from: http://www.scidev.net/global/author.aleem-ahmed.html.

Appiah, B., Gastel, B., and Burdine, J. N., 2012. The future of science journalism in Ghana: evidencebased perspectives. Journal of Science Communication, 11 (1).

Appiah, B., Gastel, B., JN, B., and LH, R., 2015. Science reporting in Accra, Ghana: Sources, barriers and motivational factors. Public understanding of Science, 24 (1), 23-37.

Aram, A., 2011. The fallacy of balance in communicating climate change. Media Development, 4/2011, 24-27.

Asoro, R. L. S., 2012. The effects of press freedom and biotech policy on Southeast Asian newspapers' coverage of genetically modified crops. MA Dissertation, Iowa State University.

Bakker, P., 2012. The rise of free daily newspapers in Latin America. Revista de Communication, 11, 129-149.

Bauer, M. W., Yulye Jessica, Ramos, R., Massarani, L., Amorim, L., and Howard, S., 2013. Global science journalism report: working conditions \& practices, professional ethos and future expectations. Our learning series, Science and Development Network. London, UK: London School of Economics and Political Science.

Boykoff, M., 2010. Indian media representations of climate change in a threatened journalistic ecosystem. Climatic Change, 99, 17-25.

Castelfranchi, Y., Massarani, L., and Ramalho, M., 2013. War, anxiety, optimism and triumph: a study on science in the main Brazilian TV news. Journal of Science Communication, 13 (3).

Chanda, M., Mchombu, K., and Nengomasha, C., 2008. The Representation of HIV/AIDS in the Media and its Impact among Young People in Namibia: a study of Windhoek and Katima Mulilo. Information Development, 24 (3), 188-203.

Chen, F., Shi, Y. \& Xu, F., 2009. An analysis of the Public Scientific Literacy study in China. Public understanding of Science, 18 (5), 607-616.

Dafang, H., Tian, Z., and Tongqing, Y., 2011. China: Beyond Technology: Initiatives to Popularize Genetic Modification. In: Navarro and Randy A. Hautea., M. J., ed. Communication Challenges and Convergence in Crop Biotechnology. Los Baños, Philippines: International Service for the Acquisition of Agri-biotech Applications (ISAAA): Ithaca, New York and SEAMEO Southeast Asian Regional Center for Graduate Study and Research in Agriculture (SEARCA).

Das, J., 2012. Environmental journalism in Bangladesh Active social agency. Journalism Studies, 13 (2), 226-242. 
DeRosier, C., Sulemana, I., Jr, H. S. J., Corinne Valdivia, Folk, W., and Smith, R. D., 2015. A comparative analysis of media reporting of perceived risks and benefits of genetically modified crops and foods in Kenyan and international newspapers. Public understanding of Science, 24 (5), 563-581.

Dickson, D., 2012. Debate erupts over whether science journalists must have a background in science [online]. Available from: https://scidevnet.wordpress.com/2012/09/20/debate-erupts-overwhether-science-journalists-must-have-a-background-in-science/.

Du, L. and Rachul, C., 2012. Chinese newspaper coverage of genetically modified organisms. $B M C$ Public Health, 12 (236).

Dutt, B. and Garg, K. C., 2000. An overview of science and technology coverage in Indian Englishlanguage dailies. Public understanding of Science, 9, 123-140.

Dutt, B. and Garg, K. C., 2012. S\&T coverage in English-language Indian dailies. Journal of Science Communication, 11 (3).

Ekanem, I. A., 2003. Communicating science information in a science- unfriendly environment: the experience of Nigeria. Public understanding of Science, 12, 203-209.

Escobar, A., 1995. Encountering Development The making and unmaking of the Third Word. New Jercey: Princeton University Press.

Evans, S., 2015. Journalistic Norms, Cultural Values, and Coverage of Climate Change in the Philippines. Environmental Communication, 10 (4), 492-507.

Fang, X., 2014. Local people's understanding of risk from civil nuclear power in the Chinese context. Public understanding of Science, 23 (3), 283-298.

Farr, A. C., Witte, K., Jarato, K., and Menard, T., 2006. The Effectiveness of Media Use in Health Education: Evaluation of an HIV/AIDS Radio Campaign in Ethiopia. Health Communication, 10 (3), 225-235.

Gao, J., Fu, H., Lin, L., Nehl, E. J., Wong, F. Y., and Zheng, P., 2013. Newspaper coverage of HIV/AIDS in China from 2000 to 2010. AIDS Care, 25 (9), 1174-1178.

Gray, J., Bounegru, L., and Chambers, L., 2012. Chapter 1: Introduction. In: Gray, J., Bounegru, L., and Chambers, L., eds. The data journalism handbook. USA: O'Reilly.

Han, J., Sun, S., and Lu, Y., 2017. Framing Climate Change: A Content Analysis of Chinese Mainstream Newspapers from 2005 to 2015. International Journal of Communication, 11, 28892911.

Hinnant, A. and Len-Ríos, M. E., 2009. Tacit Understandings of Health Literacy: Interview and Survey Research With Health Journalists. Science Communication [online], 31 (1), 84-115. Available from: https://doi.org/10.1177/1075547009335345. 
Jalarajan, R. S. and Sreekumar, R., 2011. The Commercial Misrepresentation of Environmental Issues: Comparing Environmental Media Coverage in the First World and the Developing Nations. Amity Journal of Media and Communication Studies, 1 (2), 1-11.

Jia, H. and Liu, L., 2014. Unbalanced progress: The hard road from science popularisation to public engagement with science in China. Public understanding of Science, 23 (1), 32-37.

Joubert, M., 2007. South Africa: Building capacity. In: Bauer, M. W. and Bucchi, M., eds. Journalism, Science and Society. NewYork: Routlege.

Jurberg, C., Verjovsky, M., and Affonso-Mitidieri, O. R., 2009. Embryonic stem cell: A climax in the reign of the Brazilian media. Public Understanding of Science, 18 (6), 719-729.

Kakonge, J. O., 2011. The role of Media in the Climate Change Debate in Developing Countries. Global Policy Essay, November 2.

Kakonge, J. O., 2012. Fostering Partnerships With Media Organizations to Improve Climate Change Coverage in Africa. Science communication, 35 (3), 411-416.

Kasoma, F. P., 2000. The Zambian newspapers and AIDS. In: Bajo, S. T. W. and Arnaldo, C. A., eds. Media HIV/AIDS in East and Southeast Africa: A resource book. Paris: UNESCO, 121-131.

Kothari, A., 2014. The Ethics of Keeping HIV/AIDS Newsworthy in Tanzania. Journalism Practice, 9 (2), 200-214.

Kuppuswamy, S. and Maheswari, M. D., 2014. Climate change coverage in newspapers: A comparative study of The Hindu and The Times of India. Indian Journal id Science Communication, 13 (2), 3-15.

Kwenda, J. C., 2013. Environmebtal NGOs as news sources: a sociological approach to the study of environmental journalism in South Africa. Global media journal (African Edition), 7 (1), 67-91.

Le, H. T. and Navarro, M. J., 2011. Vietnam Paving the Way for Greater Awareness and Understanding of Biotechnology. In: Navarro, M. J. and Hautea., R. A., eds. Communication Challenges and Convergence in Crop Biotechnology. Los Baños, Philippines.

Linda, N. G., 2000. The coverage of HIV/AIDS in Ugandan Media: A content analysis Study. In: Bajo, S. T. K. and Arnaldo, C., eds. Media HIV/AIDS in East and Southern Africa: A rerource book. Paris: UNESCO.

Lo, Y.-Y. and Peter, H. P., 2015. Taiwanese life scientists less "medialized" than their Western colleagues . Public understanding of Science, 24 (1), 6-22.

Lü, L., 2009. The value of the use of biotechnology: public views in China and Europe. Public understanding of Science, 18, 481-492.

Lubinski, J., Inka-Reicher, D., Flaeury, J., Labasssi, O. \& Spurk, C. 2014. Advances in African and Arab science journalism: Capacity building and new newsroom structures through digital peer- 
to-peer support. Ecquid Novi: African Journalism Studies, 35 (2), 4-22.

Lugo-Ocando, J. and Nguyen, A., 2017. Developing News: Global Journalism and the Coverage of Development in the "Third World". London: Routledge.

Lynas, M., 2018. Shadows and mirrors: GMOs in China [online]. 2017. Available from: https://allianceforscience.cornell.edu/blog/2017/05/shadows-and-mirrors-gmos-in-china/.

Maillé, M.-È., Saint-Charles, J., and Lucotte, M., 2009. The gap between scientists and journalists: the case of mercury science in Québec's press. Public Understanding of Science [online], 19 (1), 7079. Available from: https://doi.org/10.1177/0963662509102690.

Majumdar, P. and Saikia, B. C., 2011. Science Coverage in Regional Newspaper: A Case Study of Two Newspapers from North East India. In: The 11th International Conference on Public Communication of Science \& Technology. New Delhi, India.

Masood, E., 2005. The GM Debate - Who Decides? An analysis of decision-making about genetically modified crops in developing countries . Panos Report. London: The Panos Untitution.

Massarani, L., 2013. Developing world and science communication research. Journal of Science Communication, 12 (1).

Massarani, L., 2014. Science communication in Latin America: what is going on? Science Museum Group Journal, Autumn 201 (2).

Massarani, L., 2015. Voices from other lands. Public Understanding of Science, 24 (1), $2-5$.

Massarani, L. and Buys, B., 2007. Science in the press in nine Latin American Countries. Brazilian Journalism Research, 3 (2), 77-96.

Massarani, L., Buys, B., Amorim, L. H., and Veneu, F., 2005. Science Journalism in Latin America: A case study of seven newspapers in the region. Journal of Science Communication, 4 (3).

Mazzonetto, M., 2005. Science communication in India: current situation, history and future developments. Journal of Science Communication, 4 (1).

Mchombu, K. J., 2000. The coverage of HIV/AIDS in Namibian Media: A content analysis Study. In: Bajo, S. T. K. and Arnaldo, C., eds. Media HIV/AIDS in East and Southern Africa: A rerource book. Paris: UNESCO.

Mercado, M. T., 2012. Media representations of climate change in the Argentinean press. Journalism Studies, 13 (2), 193-209.

Michael, E. J. and Binta, O. D., 2013. Reportage of Science and Environmental Issues In Selected Nigerian Newspapers. The International Journal Of Science \& Technoledge, 1 (6), 22-27.

Midttun, A., Coulter, P., Gadzekpo, A., and Wang, J., 2015. Comparing media framings of climate change in developed, rapid growth and developing countries: Finding from Norway, China and 
Ghana. Energy and Environment, 26 (8), 1271-1292.

Mumba, L. E., 2007. Food Aid Crisis and Communication about GM Foods: Experience from Southern Africa. In: Brossard, D., Shanahan, J., and Nesbitt, T. C., eds. The public, the media and agricultural biotechnology. The United Kingdom: Biddles Ltd, Kings Lynn, 338-364.

Mwale, P. N., 2006. Societal deliberation on genetically modified maize in southern Africa: the debateness and publicness of the Zambian national consultation on genetically modified maize food aid in 2002. Public understanding of Science, 15, 89-102.

Nguyen, A \& Tran, M, 2019). "Science journalism for development in the Global South: A systematic review of its characteristics, issues and challenges. Proceedings of the $69^{\text {th }}$ Annual Conference of the International Communication Association, Washington, DC, 24-28 May, 2019.

Navarro, M. J., Panopio, J. A., and Malayang, D. B., 2011. Print media reportage of agricultural biotechnology in the Philippines: a decade's (2000-2009) analysis of news coverage and framing. Journal of Science Communication, 10 (3).

Naz, F., 2006. Artuno Escobar and the development discourse: An overview. Asian Affairs, 28 (3), 64 84.

Ndlovu, H., Joubert, M., and Boshoff, N., 2016. Public science communication in Africa: views and practices of academics at the National University of Science and Technology in Zimbabwe. Journal of Science Communication, 15 (6).

Nelkin, D., 1995. Selling Science How the press covers science and technology. NewYork: W.H. Freeman and Company.

Nguyen, A., 2014. The current status of science journalism in Southeast Asia. Unpublished Research Report Prepared for the World Federation of Science Journalists.

Ogbogu, U., Du, L., Rachul, C., Bélanger, L., and Caulfield, T., 2013. Chinese Newspaper Coverage of (Unproven) Stem Cell Therapies and their Providers. Stem Cll Rev and Rep, 9, 111-118.

Ogodo, O., 2012. Sudanese media have a rich history, but they have failed to cover science. SciDev Net. https://scidevnet.wordpress.com/2012/09/20/sudanese-media-have-a-rich-history-but-theyhave-failed-to-cover-science/.

Olet, P. and Othieno, J., 2015. How to do mass media publicity for a neglected disease. Lessons from Tsetse and Trypanosomiasis in Kenya. Journal of Science Communication, 14 (03).

Panopio, J. A. and Navarro, M. J., 2011. Philippines:Drama and Communication Behind Asia's First Commercialized Bt Corn. In: Hautea, R. A., ed. Communication Challenges and Convergence in Crop Biotechnology. Los Baños, Philippines.

Patairiya, M., 2007. Challenges and Prospects of Science Communication in South Asia. Indian Journal of Science Communication, 6 (1), 9-16. 
Patairiya, M., 2014. Science Journalism in India [online], 2/16/2014. Available from: http://www.pantaneto.co.uk/issue25/patairiya.htm.

Patil, D. M., 2011. Recent trends of print media in development communication. Global Media Journal (Indian Edition), 2 (2).

Peters, HP, 2013. Gap between science and media revisited: Scientists as public communicators. Proceedings of National Academy of Science. 110:14102-14109.

Plantinga, B., 2012. Newspaper publishing. In: Myburgh, V., Smith, E., Liebenberg, S., and Jager, L. de, eds. South African entertainment and media outlook: 2012-2016. South Africa: PricewaterhouseCoopers, 171-189.

Plessis, H. du, 2008. Public communication of science and technology in developing countries . In: Trench, B., ed. Handbook of public communication of science technology. Ofxord : Routledge.

Pratt, C. B. and Ha, L., 2002. Setting the Public Health Agenda on Major Diseases in Sub-Saharan Africa: African Popular Magazines and Medical Journals, 1981-1997 . International Communication Association, 52 (4), 889-904.

Raj, S. J. \& Sreekuma, R., 2011. The Commercial Misrepresentation of Environmental Issues: Comparing Environmental Media Coverage in the First World and the Developing Nations. Amity Journal of Media and Communication Studies, 1(2), 1-11.

Ramalho, M., Massarani, L., and Polino, C., 2012. From the laboratory to prime time: science coverage in the main Brazilian TV newscast. Journal of Science Communication, 11 (2)

Reis, R., 2008. How Brazilian and North American Newspapers Frame the Stem Cell Research Debate. Science communication, 29 (3), 316-334.

Ren, J., Peters, H. P., and Lo, Y.-Y., 2014. Similar challenges but different responses: Media coverage of measles vaccination in the UK and China. Public understanding of Science, 23 (4), 366-375.

Schafer, M. S., 2010. Taking stock: a meta-analysis of studies on the media's coverage of science. Public understanding of Science. Online first version. https://journals.sagepub.com/doi/abs/10.1177/0963662510387559.

Schäfer, M. S., Ivanova, A., and Schmidt, A., 2012. Media attention for climate change around the world: A comparative analysis of newspaper coverage in 27 countries. Global Environmental Change, 23 (5), 1233-1248.

Schanne, M., Spurk, C., and Wawira, J., 2009. Feasibility Study 'Enabling Health Journalism'. Zurick University: School of Applied Linguistics IAM Institute of Applied Media Studies Research.

Shanahan, M., 2006. Fighting a reporting batte. Nature, 443, 392.

Shanahan, M., 2009. Time to Adapt? Media Coverage of Climate Change in Nonindustrialised Countries. In: Lewi, J., ed. Climate Change and the Media. Peter Lang Publishing. 
Shrestha, S., Burningham, K., and Grant, C. B., 2014. Constructions of Climate Change on the Radio and in Nepalese Lay Focus Groups. Environmental Communication, 8 (2), 161-178.

Soete, L., 2016. Unesco Science Report (2015) toward 2030. In: Round Table Discussion on Monitoring STI for SDG. United Nation Headquarters.

Subudhi, R., 2015. Role of Print-Media in Socio-economic Development of East-India. Subudhi, Rabi, Role of Print-Media in Socio-Economic Development of East-India (July 1, 2015). Conference Proceedings, ICAS (International Conference of Asian Scholars), Adelaide, Australia, July 2015. Available at SSRN: https://papers.ssrn.com/sol3/papers.cfm?abstract id=2757973.

Tagbo, E., 2010. Media Coverage of Climate Change in Africa A Case Study of Nigeria and South Africa. University of Oxford: Reuters Institute Fellowship Paper University of Oxford.

Takahashi, B., 2011. Framing and sources: a study of mass media coverage of climate change in Peru during the V ALCUE. Public understanding of Science, 20 (4), 543-557.

The Lancet, 2016. Global burden of disease study 2015 assesses the state of the world's health [online]. ScienceDaily. Available from: https://www.sciencedaily.com/releases/2016/10/161006102549.htm.

Tolan, S., 2007. Coverage of climate change in Chinese media (Fighting climate change: Human solidarity in a divided world).

UNESCO, 2007. Developing a science journalism course for the developing countries. A report on the UNESCO workshop and questionaire conducted in association with the World Conference of Science Journalists, April 26-19-2007.

UNESCO, 2010. UNESCO Science Report 2010. Poland: UNESCO Publishing.

UNESCO, 2011. Media Coverage of Science and Technoogy in Africa. Uganda: Makerere University.

Veneu, F., Massarani, L., and Amorim, L. H., 2008. Science journalism in Latin America: how the scientific information from a scientific source is accommodated when it is transformed into a journalistic story. Journal of Science Communication, 7 (1).

Wahyuni, H. I., 2017. Challenges for journalism education in Indonesia. Pacific Journalism Review, $23(1), 80-95$.

WHO, 2009. Global health risks: mortality and burden of disease attributable to selected major risks. Switzerland.

Xu, L., Huang, B., and Wu, G., 2015. Mapping science communication scholarship in China: Content analysis on breadth, depth and agenda of published research. Public understanding of Science, 24 (8), 897-912.

Yang, J., Xua, K., and Rodriguez, L., 2014. The rejection of science frames in the news coverage of the golden rice experiment in Hunan, China. Health, Risk \& Society, 16 (4), 339-354. 
Zamith, R., Pinto, J., and Villar, M. E., 2012. Constructing Climate Change in the Americas: An Analysis of News Coverage in U.S. and South American Newspapers. Science communication, 35 (3), 334-357.

Zhang, Y., Jin, Y., and Tang, Y., 2015. Framing Depression: Cultural and Organizational Influences on Coverage of a Public Health Threat and Attribution of Responsibilities in Chinese News Media, 2000-2012. Journalism \& Mass Communication Quarterly, 92 (1), 99-120.

Zhao, F., Chen, Y., Ge, S., Yu, X., Shao, S., Black, M., Wang, Y., Song, M., and Wang, W., 2014. A Quantitative Analysis of the Mass Media Coverage of Genomics Medicine in China: A Call for Science Journalism in the Developing World. A Journal of Integrative Biology, 18 (4), 222-230.

Zhao, X., 2012. Personal Values and Environmental Concern in China and the US: The Mediating Role of Informational Media Use. Communication Monographs, 79 (2), 137-159. 